\title{
Scope of ornamental fisheries in snow fed rivers of Uttarakhand - Overview
}

\author{
Anita*, Akansha Khati, Maneesh Kumar Dubey and N. N. Pandey \\ Department of Aquaculture, College of Fisheries, G. B. Pant University of Agriculture and Technology, \\ Pantnagar-263145 (Uttarakhand), INDIA \\ *Corresponding author E-mail: anitatamta20@gmail.com
}

Received: February 13, 2015; Revised received: July 20, 2015; Accepted: August 26, 2015

\begin{abstract}
Upland rivers of hills of Uttarakhand are unique in its ecosystem and biodiversity. These waters possess various varieties of ornamental fishes. The present study focuses on Scope of ornamental fisheries in snow fed rivers of Uttarakhand, along with challenges and opportunities. Besides the availability of resources peoples are not that much aware of ornamental fisheries of this region and these resources are yet not developed. The use of destructive fishing methods, habitat destruction leads to diversity destruction of hills stream fishes. As these resources does not comprise fisheries of commercial importance due to sparse biota and low thermal scale, slow growth and very low natural food availability So, Directorate of Cold Water Fisheries is actively working in the field of survey and brood stock management of ornamental fish resources of cold water. Four hundred live cold water fishes including exotic gold and koi carp are being maintained at DCFR main complex for study and breeding trials. The recreational activities by fisheries department like ranching, sport fisheries development and development of ornamental fisheries of this region can lead to socioeconomic upliftment of hilly people and development of cold water ornamental fisheries in the state.
\end{abstract}

Keywords: Glacier , Mahseer, Ornamental fisheries, Socioeconomic upliftment

\section{INTRODUCTION}

In India, upland waters (Himalayas and the peninsular plateau) possess 258 fish species belonging to 21 families and 76 genera (ICAR, 2011) Out of which 203 species are found in upland Himalayan waters and remaining in Deccan plateau (Mahanta and Sharma, 2010). Uttarakhand formed in 9 November, 2000 is a hilly state of $53483 \mathrm{~km}^{2}$ geographic area of which $93 \%$ is mountainous and reaming part is covered by the forest. Northern part of the state is mostly part of Greater Himalayan ranges, high mountains, glaciers, peaks (State profile, 2011) The fish and fishery resources of Himalayan and Indio Gangatic plains attracted interest of various ichthyologists as Hora, 1937 and 1939, Shrestha (1990) studied the ornamental fishes of Himalayan waters and Talwar and Jhingran (1991). Himalayan ecosystem is unique in its biodiversity and it is the origin point of two mightiest river system of India i.e. Ganga river system from Gaumukh glacier at a height of 3,892 m on the south western slopes of Banderpooch peaks and Yamuna river from Yamunotri glacier at the elevation of 6,387 $\mathrm{m}$ having so many tributaries like Alaknanda, Pinder, Mandakini, Bhagirathi, Bhilangana, and Tons along with many small streams, gaad and gadheras and Koshi, Ramganga Kali, Lohawati, Ladiya, Gaggas river stretches in Kumaon region of Uttarakhand, are fed by myriad lakes, melting glaciers, small springs and several streams (FAO. 2002; Seth et al., 2014). Many stretches of these river systems are known for angling activities. The beginning of sport fishing through a modern concept as such could be seen in India during the third century BC when the great economist, Chanakya, formed the laws for regulating Fishing and conservation in the time of emperor Ashoka. Later, during the $12^{\text {th }}$ century AD King Somesvara gave detailed account of angling in the chapter 'Matsyavinod' (Tripathi, 2009). The total length of river system of Uttarakhand is about 2,686 $\mathrm{km}$. These resources receive water from snow melting from glaciers. In terms of species diversity, upland waters of Uttarakhand possess 83 species belonging to 39 genera, 12 families and 3 orders out of which 8 species are of ornamental value, 5 species are of sport fisheries and 40 species have food value (Mahanta et al., 2009). The temperature tolerance of the hill stream fishes is very narrow mostly stenothermal which plays very important role in their distribution and dispersion. These fishes are endowed with great power of locomotion and they are well adapted to withstand the fast water current and high dissolved oxygen levels. These water bodies are snow fed, situated at high altitude and are oligotrophic, do not support the diverse group of planktonic flora, fauna and benthic organisms (Kumar et al., 2012). Khanna et al., (2013) studied the fish diversity and limnological status of Ganga river system in foothills of Garhwal Himalaya of Uttarakhand. 
These water bodies are under serious threat of over exploitation and destructive fishing activities especially fish poisoning through local plants which in turns reduces the population of fishes in nature (Negi and Kanwal, 2009). Now the time is to recognize and develop aquatic resources as a part of integrated approach in terms of sustainable livelihood and rural development of upland areas. Malik and Bharti (2012) studied the Sahastradhara stream of Uttarakhand its plankton biodiversity status and biological productivity. Shrestha (1990) studied the conservation and management of fishes in the large Himayayan rivers of Nepal and he concluded that recreational activities, establishing fish sanctuaries, parks, aquariums along the river stretch will attract the tourists and also increases the awareness amongst the local peoples about the economic importance of fish and fisheries resources. Khanna and Badola (1990) studied the ichthyo fauna of foothills of Garhwal Himalaya and they also stated that the unique ecosystem of snow fed rivers of Uttarakhand is full of aquatic biodiversity and needs the attention of the researchers. Saxena et al. (2009) studied the ecotourism in India with special reference to angling in Uttarakhand. They also concluded that there is immense scope of angling in the state and needs development and attention of local people. Attempts have been made by Directorate of Cold Water Fisheries Research of developing brood banking of some ornamental fish species and some other important coldwater fish species viz. Tor putitora, Tor chillinoides, Labeo dero, Schizotharax richardsoni, Barilius bendelensis, Barilius vagra, Nemachilus sp., Gara gotyla gotyla etc from various rivers of Kumoun, Uttarakhand viz Gola, Chafee, upper Kosi, lower Kosi, kali ,Gomati, western Ramganga and Saryu river (DCFR, 2014). The present review aims to study the scope of ornamental fisheries in snow fed rivers of Uttarakhand for livelihood security and recreational fisheries.

\section{MATERIALS AND METHODS}

The snow fed rivers of hills comprises various fishes like mahseers like Tor putitora and Tor tor, minor carps like Labeo dero, L. calbasu, cat fishes like glyptothorax, loaches, salmonids like Brown trout (Salmotrutta fario), Schizothorax richardsonii (snow trout) etc. The ornamental fish diversity of snow fed rivers is given in Table 1 . The planktonic diversity of hill streams is not so wide. It shows seasonal variation in their distribution (Bhatt et al., 1984). The planktonic diversity includes mostly Chlorophyseae, Bacillariophyceae and Euglenophysae etc. but not in very high amount. These streams show clear water with high dissolved oxygen content and carbon dioxide almost nil this condition shows no pollution in this zone.

There are so many fish species found in the snow fed rivers of Uttarakhand which have great potential as pharmaceutical use and rich in proteins, fats, vitamin A and $\mathrm{D}, \mathrm{Fe}^{2+}, \mathrm{Ca}^{+}$and minerals (Bartwal et al., 2013). DCFR (2014) surveyed some river stretches of Kumaon hills Kosi, Ramganga, Ladiya, Lohawati and Gaggas for ornamental fish resources and found fishes viz.Tor putitora, Schizothorax richardsonii, Barilius vagra and Garra gotyla gotyla. In Ramganga he observed Puntius ticto, Crossochelius latius latius and Barilius bendelensis. . Patiyal (DCFR 2014) also surveyed river system of Kumoun region of Uttarakhand for ornamental fish germplasm exploration. 400 fish species from different rivers i.e Kali, Gomti, Saryu, Kosi, Chafee, Gola like Tor putitora, Tor chillinoides, Barilius spp., Nemachelius spp., Garra spp., Carracius spp., and Koi carp is being reared in ornamental Brood Bank (DCFR 2014). DCFR, Bhimtal is currently emphasizing on brood stock raising and seed production of koi carp and gold fish. The institute is also actively engaged in ornamental fish culture in Pithoragarh, Dharchula, Almora and other hill districts of Kumaon region of Uttarakhand. Singh and Agarwal,(2014) studied the Assiganga stream tributary of Bhagirathi river of central Himalaya, its habitats and substratum features important for fish biodiversity. They concluded that the abundant benthic food, optimum water quality serves ideal conditions for survival of snow trout, loaches, Tor spp., and other trout species.

\section{CURRENT ISSUES AND FUTURE PROSPECTS}

Present problems: Construction of dams not only obstructs the path of rivers but also the spawning migration of fishes (especially mahseer) leads to reducing population of fishes from the rivers and alteration in hydrobiological regime of water. The mismanaged water and fish passes and reservoir siltation due to deforestation adversely affect the fish population (FAO, 2002).

The Hill streams are poorly developed in terms of fisheries and are under serious threat of fish poisoning, destructive fishing activities. As a result mostly fishes are endangered or threatened (FAO, 2002).

Destructive methods of fishing, fish poisoning, dynamiting and lack of insufficient funds and less research activities are the major loopholes of hill ornamental fisheries exploration (Ngacltan et al., 2009).

Presently climate change and its impact is major factor in distribution of diversity of fishes, planktons and other organisms (WICCI, 2011).

Conservation strategy: Conservation based fisheries management of upland hill stream diversity is recent in origin and which need not only research and capacity building, but also Bioregional management, the designation of endangered and threaten species for protecting biodiversity, stock enhancement.

The upland biodiversity of the state should be conserved although Directorate of Cold Water Fisheries, Bhimtal is the research institute of ICAR actively working in this field. 
Table 1. Taxanomic identification of the ornamental fishes of snow fed rivers.

\begin{tabular}{|c|c|c|c|c|}
\hline Order & Family & Genus & Species & Common name \\
\hline \multirow[t]{19}{*}{ Cypriniformis } & Cyprinidae & Brachydanio & rerio & Zebra fish \\
\hline & & Danio & devario & \\
\hline & & Botia & almorhae, & - \\
\hline & & Barillius & bendelisis & - \\
\hline & & & bakeri. & - \\
\hline & & & vagra & - \\
\hline & & Barbus & conchonius & - \\
\hline & & & ticto & - \\
\hline & & Labeo & dero & - \\
\hline & & Carassius & carassius & Crucian carp \\
\hline & & & auratus & Gold fish \\
\hline & & Cyprinus & carpio & Common carp \\
\hline & & Tor & putitora & Golden mahseer \\
\hline & & Tor & chillinoides & \\
\hline & Cobitidae & Gara & gotyla gotyla & Gara \\
\hline & & Nemachelius & botia & Botia \\
\hline & & & montanus & - \\
\hline & & Acanthocobitis & botia & \\
\hline & & Lepidocephalus & guntea & - \\
\hline
\end{tabular}

Priorities should be given on research related to survival of endangered fish species.

Fish Sanctuary should be developed for food fishes and as well as ornamental fishes and sport fishes where fishing should be banned.

In place of introduction of exotic ornamental fishes captive breeding and seed production of our native ornamental fishes should be developed.

The rare fish species should be conserved, all the fishing activities should be banned during spawning season and destructive fishing activities, poisoning should be strictly prohibited.

The catch from the rivers and fish diversity of the rivers regularly studied and documented to avoid overfishing or over exploitation of these resources.

Recreational activities: These fishes can be kept in small glass tanks or aquariums well equipped with water filter and aerators. Artificial feeds are easily available in markets for the aquarium fishes. One can develop ornamental fisheries as an entrepreneur.

Trainings on various aspects of ornamental fish keeping, captive breeding and culture should be organized at field and regular surveying should be done in the field by the Department of Fisheries, Uttarakhand.

The stretches of these river systems which are famous for angling activities should be developed as sport fisheries sites for promotion of sport fishery based ecotourism in the state. Water sports can also be developed in the snow fed rivers like river rafting.

Mitigation efforts for re establishment of endangered species should be done in order to restore the species and efforts for increasing awareness amongst the local community related to ornamental fisheries of local region should be done.

\section{Conclusion}

The snow fed rivers of Uttarakhand has immense potential as ornamental fish resource of the region. Various indigenous and exotic ornamental fishes have been surveyed and captured for captive breeding and brood stock development by Directorate of Cold Water Fisheries. It is of paramount importance that maintenance of aquatic biodiversity is required for the sustainable development for the people inhabiting the geographical areas of Himalayas. The source of economy mainly depends on agriculture and tourism aspects of mountains in the form of scenic beauty, river rafting, fishing in cold water stream, river dams etc. Aquatic tourism also provides potential benefits to the villagers and farmers living in the harsh environmental conditions of the Himalayas. For reducing migration from the hills and generating Ornamental fisheries and sport fisheries based ecotourism for small scale enterprise in the hills can provide an alternative source of employment and livelihood security to the hilly region people. Ornamental fisheries of the region should be enhanced and the techniques of brood stock development and captive breeding of ornamental fishes of local area should be developed. Recent success of developing aquaculture in mountain areas of India shows that fish farmers in the rural areas can become the direct beneficiaries of the implementation of inexpensive aquaculture technologies, and as a consequence achieve significant improvement in their standard of living.

\section{ACKNOWLEDGEMENT}

The authors are highly grateful to Dean, College of Fisheries, Govind Ballabh Pant University of Agriculture 
and Technology and DCFR, Bhimtal for support and guidance.

\section{REFERENCES}

Bartwal, M., Singh, D. and Bhandari, M.S. (2013). Assessment of ecology of aqua-biodiversity and economical development through aquatic tourism in Uttarkashi, Uttarakhand, India.

Bhatt, S.D., Bisht , Y. and Negi, U. (1984). Ecology of the limnofauna in the

River Koshi of the Kumaun Himalaya (Uttar Pradesh)). Proc. Indian Natn. Sci. Acad. B50 No 4 pp 395-405.

Data of State profile demography (2011). Government of Uttarakhand. http://www.ukhfws.org/

DCFR, Directorate of Cold Water Fisheries, (2014). Annual report, 2013-2014.

Food and Agriculture Organization (FAO) (2002). Cold water fisheries in the trans-Himalayan countries. Petr, T.; Swar, D.B. (eds.). FAO Fisheries Technical Paper. No. 431 Rome, p. 376.

Hora, S.L. (1937). Comparison of the Fish Fauna of Northern and Southern Faces of the Great

Himalayan Region. Record of Indian Museum, 39:1-250.

Hora, S.L. (1939). The Game Fishes of India. VIII The Mahseer and Large Scale Barbels of

India. I. The Putitor Mahseer, Barbus Tor putitora (Hamilton). Journal of Bombay

Natural History Soc., 41 (2): 272-285.

ICAR (2011). Handbook of Fisheries and Aquaculture (2 ${ }^{\text {nd }}$ ed.). Indian Council of Agriculture and Research, New Delhi.

Khanna, D.R., Bhutiani, R. and Ruhela, M., (2013). Fish diversity and their limnological status Of ganga river system in foothills of garhwal Himalaya, uttarakhand, india. J. Environ. Res. Develop.,7(4):1374-1380.

Khanna D.R. and Badola S.P., (1990). Ichthyo fauna of foot-hills of Garhwal Himalaya, J. Nat.

Phy. Sci., 4(1-2): 153-162.

Kumar, P., Wanganeo, A., Sonaullah, F. and Wanganeo, R. (2012). Limnological Study on two High Altitude Himalayan Ponds, Badrinath, Uttarakhand. International Journal of Ecosystem, 2 (5): 103-111.

Mahanta, P.C., Joshi, K.D. and Ayyappan, S. (2009). Strategies for coldwater fisheries development in India. National Symposium on Coldwater Fisheries Management: New
Strategies and Approaches. 2-4 October, 2009.

Mahanta, P.C., Sarma, D. (2010). Cold Water Fisheries Management. pp- 1-451.

Malik, D.S., and Bharti, Umesh (2012). Status of plankton diversity and biological productivity of Sahastradhara stream at Uttarakhand, India. Journal of Applied and Natural Science 4 (1): 96-103.

Negi, K.S. and Kanwal, K.S. (2009). Plants used as fish toxins in Garhwal region of Uttarakhand Himalaya. Indian Journal of Traditional Knowledge Vol. 8 (4) pp 535-538.

Ngacltan, S.V., Das, S.K., Basudha, Cit. and Murmu, K. (2009). Need for conservation of the endangered chocolate mahseer, Neolissocheilus hexagonolepis and golden mahseer, Tor putitora - A review. Souvenir cum Abstract Book, National Symposium on Coldwater Fisheries Management: New Strategies and Approaches 2-4 October 2009. Pp. 41-43.

Saxena, A., Sharma C.D. and Verma, V.K. (2009). Ecotourism in India with special reference to angling in Uttarakhand. Strategies for coldwater fisheries development in India. National Symposium on Coldwater Fisheries Management: New Strategies and Approaches. 2-4 October, 2009.

Seth, R., Mohan, M., Singh, P., Singh, R., Dobha, R., Singh, K.P. and Gupta, S. (2014). Water quality evaluation of Himalayan Rivers of Kumaun region, Uttarakhand, India. Appl Water Sci. DOI 10.1007/s13201-014-0213-7.

Shrestha, T.K. (1990). Rare Fishes of Himalayan Waters of Nepal. Journal of Fish Biology.

Academic Press, London, pp. 213-216.

Singh, G. and Agrawal, N.K., (2014). Fish assemblage structure and habitat use of

the snow fed stream Assiganga- a major tributary of river Bhagirathi. International Journal of Aquatic Biology. 2 (6): $305-312$

Talwar, P.K. and Jhingran, A.G. (1991) Inland Fishes of India and Adjacent Countries. Vol I and II. Oxford and IBH Publishing Co. India, $1158 \mathrm{p}$.

Tripathi S.D. (2009). Sport fishery and ecotourism. Strategies for coldwater fisheries development in India. National Symposium on Coldwater Fisheries Management: New Strategies and Approaches. 2-4 October, 2009.

Wisconsin Initiative on Climate Change Impacts (WICCI) (2011). Cold water Fish and Fisheries Working Group Report. Pp.1-34. 